\title{
DOUBLE TROUBLE: PARAFICTIONAL PERSONAS AND CONTEMPORARY ART
}

\author{
KATE WARREN
}

\section{ABSTRACT}

Across the news and entertainment media there is an increasingly prevalent phenomenon: actors, performers and artists who play "versions of themselves". This paper explores the entertaining and critical potentials of this strategy, which I term "parafictional personas". I draw upon Carrie LambertBeatty's theorisation of the parafictional as a critical mode that has developed out of (and in tension with) the "historiographic turn". Parafictional personas are a specific iteration, characterised by two key components: they compulsively imbue every opportunity with layers of interconnections and self-reflexive moments; and they involve artists and performers appropriating their own "proper name", constructing fictionalised doubles of themselves. While found widely across media, my central focus is contemporary visual art, analysing two key examples, Israeli-American artist Omer Fast and Lebanese artist Walid Raad.

These artists are significant because their personas are not simply means of performing themselves as individuals; they are integrated into the ways the artists approach contentious, still unfolding events of contemporary history. Parafictional personas have the potential to thoroughly embed fictional constructs within reality, because of the difficulties in separating elements represented by the same proper name. Their critical potential lies in the ways that they make visible the difficulties of maintaining clear distinctions between historical and fictional, social and individual narratives. Parafictional personas confound cultural desires to order, categorise and "make sense" of historical narratives. They reveal how much we as viewers (and societies) search for ideas of truth and resolution, even if such truths are presented as incomplete, questionable, or irresolvable.

\section{KEY WORDS}

Parafiction; Contemporary Art; Contemporary History; Omer Fast; Walid Raad

Across many forms of news, entertainment, and artistic media, there is a widespread phenomenon that upends and challenges the idea of the "authentic" persona: actors and performers who play "versions" of themselves. From Stephen Colbert's recently retired conservative pundit on The Colbert Report (2005-14), to French author Michel Houellebecq's subversive personal fictionalisations across novels and films, or the doubly live-action and animated figure of Robin Wright in The Congress (Ari Folman, 2013), such personas populate our cultural landscapes in multiple and diverse ways. While artists, filmmakers, writers, and gamers have long made creative use of aliases, pseudonyms, and pen names, this contemporary 
iteration relies on individuals actively appropriating their own proper name-that basic distinguisher of individuality.

This article explores the entertaining, critical and subversive potential of this highly selfconscious strategy, which I am terming "parafictional personas". Connections could be drawn between this phenomenon and contemporary forms of social media, which allow individuals to actively and publically present themselves. Yet rather than cultivating an authentic or desirable self-image, parafictional personas are characterised by their conscious fictionalisations and unreliability. They immediately reveal the limitations to ingrained cultural desires for truth and authenticity. For this reason, I draw upon Carrie Lambert-Beatty's theorisation of the "parafictional" as a critical concept, which has developed out of (and in tension with) the "historiographic turn". Under this framework, I consider the implications of appropriating one's own proper name, analysing two central examples: Lebanese artist Walid Raad and IsraeliAmerican artist Omer Fast. These two artists are significant because their personas are not simply used as means of performing themselves as individuals. Rather, they are integrated into the ways these artists approach often contentious, still unfolding events of contemporary history. Exploring these practices also illuminates how the parafictional might be deployed as a critical tool. Parafictions are seductively dangerous because they threaten the truth status of their referents; constructing a fictionalised version of oneself allows for multiple levels of fiction and reality to co-exist, maintaining a sense of open-endedness and irresolvability.

\section{THE (SEDUCTIVELY) UNRELIABLE PERSONA}

In the developing discipline of persona studies, considerations of subjectivity, identity and authenticity are, understandably, topics of central concern. P. David Marshall connects these areas of inquiry to the twenty-first century's rapidly evolving media landscape, in which individuals' public selves can be consciously or unwittingly transformed through social media. For Marshall, "information and identity formation are moving differently and through layers of media and communication. Foundational in this new movement [...] is the interpersonal constitution of identity embedded in very powerful online interconnected social networks" ("Persona Studies" 163). Social networks are supplanting traditional "representational media" with "a presentational media and cultural regime", the latter facilitating widespread cultural preoccupations with publically constructing one’s identity (Marshall, "Persona Studies" 160).

Contemporary presentational media are grounded in the performance and presentation of the individual, as people (or indeed companies or organisations) present versions of themselves that they desire to be appreciated by others as true or authentic. As Barbour, Marshall and Moore write, through presentational media the "persona" can be considered as "an everyday performance, where the purpose of the presentation of self is to convince the audience [...] that the performance is genuine and authentic". The concept of "authenticity" raises highly complex questions in relation to presentational media and the study of personas more broadly (D'Cruz), because despite obvious correlations, authenticity is not equivalent to "truth". As Ruth E. Page argues, online identities are "selective and often idealized", where distinctions between the "fictional" and the "real" are destabilised and complicated (166). Nonetheless, Page observes that within contemporary self-presentational practices, there remains a persistent assumption of authenticity as being "ontologically grounded in a single self" (166). This is evident in the ways that presentational media explicitly tie their users to signifiers of individuality and authority—such as Facebook's "real name" policy, or Twitter's "verified tick".

Thus the inherently constructed nature of online identities can be easily obscured, distorted or forgotten, given that presentational media are often accompanied by social 
"expectation[s] that online identities are authentic representations of an offline self" (Marshall and Barbour 6). Artists and performers, however, are able to undercut this pervasive cultural desire to cultivate an authentic, desirable and unique self-image. Contemporary artists-such as Richard Prince, Natalie Bookchin, Penelope Umbrico and myriad others-commandeer the "search, share, and aggregate" capacities of Web 2.0 technologies, appropriating and exploiting presentational media in ways that destabilise the prioritisation of the individual and the subjective. These artists often sort through billions of images online, collecting and recontextualising them in various ways (Ritchin 6). Such practices highlight the culturally coded similarities of the content that people share on social media, undermining the "individuality" of such personal profiles. More interestingly, these artists reveal how the presumed immediacy of presentational media can be subverted and re-positioned, establishing complex feedback loops between Marshall's two media regimes-in other words, how presentational media can be represented, transformed and, even, historicised.

Other artists and performers intervene more directly with the notion of the "authentic self" by purposefully constructing ambiguous and fictionalised versions of themselves. This phenomenon of creating an unreliable "parafictional" persona is the central concern of my article. These artists and performers engage in processes of fictionalising themselves and in doing so they create levels of misrecognition and ambiguity for their viewers. This sentiment is amusingly expressed in Michael Winterbottom's film A Cock and Bull Story (2005), when lead actor Steve Coogan says: "Groucho Marx once said that the trouble with writing a book about yourself is you can't fool around. Why not? People fool around with themselves all the time". Winterbottom's film follows the flawed attempts of a group of filmmakers trying to adapt Laurence Sterne's supposedly "unfilmable" novel, The Life and Opinions of Tristram Shandy, Gentleman (1759-67). A Cock and Bull Story is highly preoccupied with the complexities (and impossibilities) of representing personal stories "truthfully" or "faithfully". These themes are also embodied in the film's actors such as Coogan, Rob Brydon, Gillian Anderson and others, who not only depict characters from Sterne's novel but also portray fictionalised, slightly exaggerated versions of themselves.

Of course, such overtly self-reflexive strategies are clearly not new; there are extensive traditions of personas, pseudonyms and pen names across artistic, literary and cinematic media. This is particularly evident in films that self-consciously consider the nature of the medium, such as Federico Fellini's 81/2 (1963) and Bob Fosse's All That Jazz (1979). Director Woody Allen is also famous for essentially playing himself across his entire career. What distinguishes many recent examples is that, unlike someone like Allen, these contemporary fictive personas actively appropriate their own proper names. This phenomenon of actors and performers explicitly playing versions of themselves is widespread across film and television (and increasingly contemporary art). Early precursors such as Seinfeld(1989-98) and the influential film Being John Malkovich (Spike Jonze, 1999) have given way to a raft of recent examples, from Larry David in Curb Your Enthusiasm to Louis C.K. in Louie. As Melanie Piper observes in her discussion of Louie, such widespread cultural examples "[allow] comedians to speak for themselves through the prism of fiction" (16).

In such examples, Piper identifies the complex relationship between "acting as" and "being" oneself, arguing that comedians like Louis C.K. exist in a "perpetual state of what could be authentic self-performance or a performance of the authentic" (15). However, when performers explicitly play "versions" of themselves, there is also a level of deception involvednot necessarily with malicious intent, but certainly aimed at sowing levels of uncertainty or misrecognition within the viewer. This sense of uncertainty is what accounts for much of their appeal. A common characteristic of many of these personas is that they are not content with 
constructing one or two layers of fiction. These artists, filmmakers and performers often imbue every opportunity with moments of self-reflexivity-layer upon layer of interconnections and self-fulfilling nods and winks. Winterbottom adds (at least) a third level of fictionalisation to $A$ Cock and Bull Story, presenting it as the "making of the making of" the film. Artist Omer Fast uses a similar construct in the artwork that I discuss later, Take a Deep Breath (2008). Consider also the first episode of season three of House of Cards (2013-), in which newly inaugurated (fictional) President Francis Underwood appears on the television show The Colbert Report, with the "real" Stephen Colbert. These are examples of spiralling interconnections between the real and the fictional that such projects revel in. As such, they are informed by a logic of supplementarity. Jacques Derrida's conception of the supplement, along with his theorisation of the "proper name", will prove useful in establishing the appeal and critical potentials of these personas.

Parafictional supplementarity is "properly seductive", to use Derrida's words, because its popular appeal lies precisely in its destabilising and irresolvable nature (Of Grammatology 151, original emphasis). The fictional additions that construct these unreliable personas are an excess or "surplus" to their "original" referents (i.e. the "real" person). However, these fictions also take the place of their objects; the supplement "adds only to replace. It intervenes or insinuates itself in-the-place-of" (Derrida, Of Grammatology 144-5, original emphasis). The fictional additions may overtake the real people or topics, but only because these referents are always already incomplete (Derrida, Of Grammatology 149). In the examples that I consider in this article, the distinctions between fact and fiction frequently prove impossible to decipher, reflecting a sense of spiralling interconnectedness and a chain of supplementation "ineluctably multiplying the supplementary mediations that produce the sense of the very thing they defer" (Derrida, Of Grammatology 157).

Derrida's understanding of undecidability and supplementarity help us to recognise that unreliable personas do not simply expose or critique the limits to authentic self-presentationthey often actively resist and flout cultural expectations around "truthful" (re)presentation more broadly. What is critically at stake in considering parafictional personas is the way that they actively contribute to and complicate the interminably complex relationships between documentary, history and fiction at play across our cultural landscape. When performers create doubled personas centred on self-presentation the implications are complex enough. When such doublings are integrated with the exploration of contemporary history and politics, the critical stakes may become even higher and more contentious. This informs my choice of key case studies-Walid Raad and Omer Fast-because their fictionalised personas are often integrated into the ways they approach still unfolding events of current affairs and history. For this reason, the "parafictional" is a useful framework for analysing these practices. As a critical concept, the parafictional emerged in the wake of (and in tension with) another influential movement, the "historiographic turn" in art, and I will spend some time briefly contextualising this development.

\section{FROM THE HISTORIOGRAPHIC TURN TO THE PARAFICTIONAL}

From the late twentieth century, there has been a clear movement in contemporary art as many artists turned to history as inspiration and topic of inquiry. This movement has been described under many names: the artist as historian, ethnographer, archivist, documentarian, archaeologist (see Godfrey, Enwezor, Foster). Curator Dieter Roelstraete classifies it more broadly as the "historiographic turn", arguing that the practices of many prominent contemporary artists are driven by an "[o]bsession with archiving, forgetfulness, memoirs and memorials, nostalgia, oblivion, re-enactment, remembrance, reminiscence, retrospection-in 
short, with the past". This historiographic turn in art was influenced by now well-established challenges to traditional historiography, by philosophers such as Michel Foucault. Key exhibitions and writings by theorists such as Roelstraete, Okwui Enwezor, Mark Godfrey and Hal Foster have established the historiographic turn as an enduring feature of recent contemporary art.

Artists working in such historiographic modes are guided by a desire to challenge traditional understandings of "objective" historical distance, often concerning themselves with forgotten histories or suppressed narratives. Yet many are still highly invested in the notion of truth, hence Roelstraete's emphasis on the archaeological nature of their practices, which he terms "the way of the shovel". Roelstraete argues that these artists are compelled to excavate the past, removing and categorising the strata of history that they encounter. However, contemporary art and entertainment culture have also demonstrated, many-times over, that the past need not be narrated within strict frameworks of "historical inquiry" in order to gain meaning and significance. Historical fictions, speculative alternate histories, filmic docu-dramas and mockumentaries have long contributed to cultural and historical understandings of the past by testing the boundaries between fact and fiction. Within this context, art historian Carrie Lambert-Beatty has theorised the concept of the parafictional as the "performative version" of the historiographic turn (56). By labelling the parafictional as performative, Lambert-Beatty is not describing a move towards performing or enacting ostensibly documentary-based approaches. She conceives of it as a disruptive strategy "powerfully and uniquely appropriate to our historical moment" (56), which involves embodying and exploiting the fictive elements inherent to acts of representation and truth seeking.

For Lambert-Beatty, the key to parafictionality is not whether a fictive construct is strictly possible but whether is it plausible. As she acknowledges, fundamental to this process is an element of deception:

In parafiction real and/or imaginary personages and stories intersect with the
world as it is being lived. Post-simulacral, parafictional strategies are oriented
less toward the disappearance of the real than toward the pragmatics of trust.
Simply put, with various degrees of success, for various durations, and for
various purposes, these fictions are experienced as fact. They achieve truth-
status-for some of the people some of the time. (54-56)

Plausibility and believability are defining factors for parafictions because they bind the fictive elements of the project to pre-existing understandings of reality. Parafictions create clear epistemological challenges to historiographic practices (academically and artistically), because they intervene within established cultural contexts, always maintaining "one foot in the field of the real" (Lambert-Beatty 54). Lambert-Beatty identifies a multitude of parafictional strategies that contemporary artists have used in the early twenty-first century, including "advertising campaigns for imaginary products, a not-really-censored exhibition, hacked museum audio tours, several never-made movies, [...] ersatz archives, questionable military units, [...] an invented critic, a fictional historian, [...] and legions of fake artists, both historical and contemporary" (56). While the plausibility and visibility of parafictions can vary greatly in breadth and intensity, they represent different creative reactions to a particular moment of social and political instability.

That moment is the post-September 11 period, which has been considered politically parafictional in its own right. Journalist Naomi Klein described 2003 as "the year of the fake", where fictional narratives and questionable rationales were systematically mobilised in response to the earlier terrorist attacks. In this light, comedian and political commentator 
Stephen Colbert coined a term that amusingly but precisely encapsulated this atmosphere: "truthiness". Premiered on the debut episode of The Colbert Report (Comedy Central, 17 October, 2005), truthiness describes the tendency to believe in ideas that we feel should be right. As Colbert describes it, truthiness is "what you want the facts to be as opposed to what the facts are. What feels like the right answer as opposed to what reality will support" (60 Minutes). Truthiness is not simply about blurring the boundaries between fact and fiction; it involves an internalisation of fictional constructs "as if" they were real, because they correspond with the subject's (or culture's) established value systems and pre-existing understandings of their world.

Indeed, Colbert's "truthiness" may have struck such a chord because it also taps into a broader sense of the inherent fictionality of our contemporary culture. The theorisation of "contemporaneity" is one of art history's most pressing dialogues today. One prominent contributor is aesthetic philosopher Peter Osborne, for whom the very idea of the "contemporary" is itself a fiction, because it relies upon and projects a non-existent unity of temporalities and subjectivities. As he writes, the contemporary "is an operative fiction: it regulates the division between the past and the present within the present" (Osborne 23, original emphasis). Osborne theorises the contemporary as a contested moment of negotiation between fictional and historical narratives, going on to argue that artists can "make visible" the fictitiousness of contemporary culture through means of collectivisation and pseudonymity. Parafictional personas connect to this strategy but expand it further. They do not simply render the fictional visible; they render visible the difficulties of ever distinguishing accurately between the historical and the fictional. Rather than reverting to collectivisation, they destabilise the audience's understanding of and encounter with the individual.

\section{WHAT'S IN A NAME? PARAFICTIONAL PERSONAS AND CONTEMPORARY ART}

Colbert's take on "truthiness" was, of course, a critique of the non-critical internalisations of fact and fiction that occur in political spheres. However, he expressed this critique by embodying and exploiting the characteristics of truthiness through his central construct: his fictive alter ego. Colbert was a high profile example of what I am terming a "parafictional persona": A fictionalised presentation of a real person that keeps "one foot in the field of the real" by appropriating the proper name of that individual. The inherently performative qualities of film, television, theatre, or stand-up comedy lend themselves to creating and inhabiting such personas. In the context of contemporary art however, there is an added complication in which the artist's unique "mark" has long connoted the quality and authenticity of the artwork, as epitomised by the artist's signature. There has, nonetheless, been a strong history of artists creating fictionalised characters to inhabit (such as Marcel Duchamp's Rrose Sélavy), or as a means of exhibiting anonymously or collectively (such as the fictional artist Claire Fontaine).ii However as writer and curator David Campany observes, "[d] espite its history of pseudonyms and heteronyms, art doesn't seem to be a field in which either makers or audiences are comfortable with the erasure of the author" (83). Furthermore, Soojin Lee has argued that art history has often ignored the "extra textual" ways that artists construct their identities and personas (27). In the context of contemporary art, fictionalising the self may still represent a radical gesture, even more so when artists construct such personas in order to tell stories of contemporary history.

Within this context contemporary Lebanese artist Walid Raad (b. 1967) is a significant figure, having transitioned from creating works under a pseudonym to performing under his own name. In 1999, Raad established The Atlas Group as a fictional collective and "foundation to research and document the contemporary history of Lebanon" (Raad 43). According to texts 
authored by Raad/The Atlas Group, one of the foundation's aims "is to locate, preserve, study and assist in the production of audio, visual, literary and other artifacts that shed light on some of the unexamined dimensions of the Lebanese civil wars of 1975 to 1991" (Raad 43). The Atlas Group maintained its documents, primarily notebooks, films, videotapes and photographs in its self-titled archive, and invited scholars, community organisers, editors, and curators to research and exhibit these documents.

Osborne discusses Raad/The Atlas Group's work in detail, as an exemplary example that "renders visible the fictitiousness of the contemporary itself" (33), arguing that Raad constructs a "dissemblance" of documentary practice. The Atlas Group's political power is due to the "productive ambiguities" that emerge through its works, which rely upon an already present "general ambiguity in the relationship between fictional and historical narratives" (Osborne 34). As Osborne writes, this is:

dependent upon, first, its creative use of anonymity, within pseudonymity, via the "Group" form (pseudonymity, one might say, is a condition of historical fictionalization); and second, the exploitation of the documentary, simultaneously, as indexical mark and pure cultural form. (33-4, original emphasis)

Osborne contends that pseudonymity is necessary for such historical fictionalisation. Certainly, it affords artists a veil of flexibility from which to construct their parafictions. In recent years however, Raad has extended his practice beyond the alias of The Atlas Group to exhibit and perform explicitly under his own name, but without abandoning the fictionalising tendencies of his earlier project. This includes the ongoing Scratching on Things I Could Disavow (2007-), a project in which Raad narrates a pseudo-history of his practice, and its intersections with the (art) histories of "the Arab world, its present and future [oscillating] between fact and fiction, documentation and interpretation" (dOCUMENTA (13)).

Raad presents Scratching on Things I Could Disavow through two key elements: a gallery exhibition that includes a variety of artworks and installations relating to contemporary politics and recent histories of the Arab art world, and a series of lectures that Raad performs as "walkthroughs" in the gallery space. One of the most memorable artworks in the exhibition is a precise miniature reproduction of one of Raad's previous exhibitions. Presented as a 1-to-100 scale maquette, Raad has "shrunk every archival document, photograph and video that The Atlas Group ever published; even the wall text is included in this miniaturized retrospective" (Rooney). The exhibition of Scratching on Things I Could Disavow consciously anticipates its performative supplement, installed as a series of "stages", waiting to be activated by Raad himself. Thus, the alias of The Atlas Group is amalgamated and folded into the broader persona, constructed over many years, of "Walid Raad": the artist and storyteller, caricatured professor, "anxious historian" and parafictional deceiver (Sharro).

In his performances Raad is a compelling figure: precise, engaging and authoritative. When I attended his gallery lecture at the 2012 dOCUMENTA (13) exhibition, I found myself noticeably oscillating between the real and the fictional, so characteristic of parafictional practices. Raad is utterly "believable" as a presenter; yet at the same time, some of the stories that he relates seem so fanciful that I found myself thinking, "This can't possibly be true", even about events I later discovered were indeed based on actual occurrences. In my mind the "true" became equally questionable, and the "fictional" became equally believable. Writer and curator Barbara Casavecchia insightfully notes that Raad's project "does its best to get you lost in translations". Scratching on Things I Could Disavow is all the more effective because it is presented not under a pseudonym, but under the name of Walid Raad, whose role and position 
in the art world is both foregrounded and undermined throughout the exhibition and performances.

Thus the complex relationship between truth and fiction is always on display in such projects, which goes some way to answering one of the key questions for this article: What is it about personas that makes them such a potent parafictional tool, and what specifically is the significance of attaching one's own name to this persona? Fictive personas are most successful when they are grounded in reality, thus appropriating one's own name anchors it inherently and inescapably to a sense of the real. It also offers the potential for more open-ended and ongoing forms of pretence, because there is no single moment where the deception is "revealed". In Lambert-Beatty's analysis, the moment of the reveal is crucial, because it triggers the audience to return to the fictive construct, to re-appreciate it with the knowledge of its deception. This characteristic of parafictions can produce complex and potentially ethically problematic effects on viewers, as Lambert-Beatty notes: "Being taken in by a parafiction, after all, is not just epistemologically destabilizing. It is humiliating. [...] It changes you, leaves you both curious and chastened" (82).

When a performer like Raad creates a version of themselves and fictionalises their own name, however, the construct is overtly visible and always on display. It is necessarily based on the assumption that viewers already have some level of understanding of the individual. This required recognisability is not necessarily at the same level of "celebrity" and stardom, which has highly informed the development of persona studies as a discipline (Marshall and Barbour 9). However, these performances do connect to discourses of celebrity as highly complimentary and "supportive of a wider appreciation of individualism and individualisation" (Marshall, "Persona Studies" 156-7). Parafictional personas immediately and specifically challenge the status and assumed primacy of the proper name as a key marker of individuality-which in fact has always been problematic. While a proper name is generally assumed to be a specific designator of a unique individual (or organisation, location, and so on), Derrida reminds us that "the proper name was never possible except through its functioning within a classification and therefore within a system of differences" (Of Grammatology 109). To comprehend something as a proper name is to understand it always in relation to common and multiple signifiers, signifiers that belong to no individual, and are therefore improper (Of Grammatology 111). If a proper name was truly unique, it could not be recognised as a designator; it must be repeatable. Thus, the proper name is constructed from a paradox: rather than referring to a singular thing, it always refers to systems of multiplicity.

Parafictional personas perform this paradox. All parafictions are repetitions in the sense that they imitate certain subjects, histories or figures. Parafictional personas amplify this by foregrounding and appropriating the relationship between the individual subject, and the signs that denote its individuality. As Derrida makes clear, even signs like one's proper name or one's signature, which are presumed to denote uniqueness or deferred presence, are always conditioned by their iterability, and hence their performativity in different contexts ("Signature

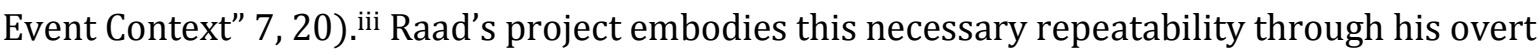
acts of doubling (and multiplying) himself symbolically and performatively. By mobilising this parafictional persona to narrate still unfolding politics and current events, Raad not only destabilises his own subjectivity, he reinforces a sense of multiplicity that is internal to these complex histories. As a "historian" Raad is concurrently convincing and unreliable; by fictionalising his stories as well as himself, Raad's performative double reinforces an understanding of history as a dynamic, shifting, unstable process. In doing so he raises the (uncomfortable) possibility that some "truths" defy understanding, and some histories may never be revealed. Scratching on Things I Could Disavow was recently presented at the Museum 
of Modern Art, New York. Tellingly, the museum's website states that Raad's performance "unlocks the meaning of all of the works that constitute the series" (MoMA). However, Raad's lectures do not "clarify" any singular meaning-they are as informative as they are confounding. Thus the museum's own characterisation exposes the lingering desire to "pin down" meaning, even when it is presented as fictionalised or uncertain. Parafictional personas expose such lingering desires, and this is particularly evident in the work of my final example, IsraeliAmerican artist Omer Fast.

\section{“OMER FAST": CONFOUNDING CERTAINTY}

The documentary really resides in the fact that the encounter involves two bodies, two people in conversation, one of whom has certain ideas that he or she wants to relate [...]. And the other body in that encounter is me: the listener, the interviewer, the confessor, the artist, the filmmaker, the idiot: all sorts of roles that I like to play with and that are there during this encounter. (Fast and Paulsen)

Omer Fast (b. 1972) is a prominent contemporary artist who works primarily in film and video installation. Unlike Raad, who actually performs himself physically through his lectures, Fast creates his fictionalised personas by writing himself into his videos, typically using actors to portray an "Omer Fast" or a "director" character. While Raad's projects give the impression of approaching the complexities of history on a macro-scale, Fast's artworks emerge from a micro-level of history and personal experience. Most of Fast's artworks are based on interviews that he conducts with individual people, from soldiers to asylum seekers, actors to undertakers. He then uses various strategies of repetition, re-telling, and re-enactment to creatively re-imagine his encounters with his subjects and their stories. Because of this reliance on interviews and individuals' stories of real-world experiences, his practice is frequently discussed within the context of "documentary". The notion that Fast "blurs the boundaries" between fact and fiction is one of the most frequently evoked qualities of his work (Cotter, Darwent, Lebovici). However, as Fast's quote at the beginning of this section demonstrates, his conception of "documentary" is always already entangled with fictionalisation, performance and role-playing.

The figure of the "double" is fundamentally important to Fast's practice; as he recently states, "[d]oubling is everything for me. I grew up in two countries with two cultures and languages and have never had a fixed unitary identity. My notion of self is completely polluted by the presence of doubles" (Fast and Albes). Fast's artistic practice palpably resists the notion of a unique, authentic self-both for himself but also in relation to his subjects and topics of inquiry. My discussion will focus on his dual-channel video installation Take a Deep Breath (2008), one of the first to include an "Omer" character. Take a Deep Breath is also significant because it consolidates many creative devices that have become defining elements of Fast's practice, as well as of parafictional personas more broadly: high levels of self-reflexivity; an ingrained use of the fictionalised "artist/director" character; and a shattering of distinctions between documentary and fictional forms.

To make the work, Fast travelled to Jerusalem to interview "Martin F", a medic who witnessed a suicide bombing during the Second Intifada. Martin's story goes along these lines: After hearing an explosion he entered the bombed-out restaurant and discovered only one victim-a young man with both legs missing. After unsuccessfully administering mouth-tomouth and CPR, the medic later realised that the man whose life he tried to save was the bomber himself (Lewis-Kraus). Martin came to regard his actions as posing a moral conundrum; 
since he carries a gun, he would have shot the young man had he known of his plans, to prevent the bombing (Lewis-Kraus).

Two days after his experience, Martin wrote an account of the bombing that went viral (Lewis-Kraus) and over the years this, Fast says, "left [Martin] with a story that has taken on a life of its own and has even eclipsed him" (Fast 43). When Fast interviewed Martin, the medic recounted his story almost by rote, having lost an embodied, flexible connection to these events. Writer Gideon Lewis-Kraus evocatively describes Martin's experiences as "[having] been so hyperactively embalmed that they have become corroded". Martin was no longer bearing witness to his subjective experience, but rather performing the role of the witness, of himself. Martin's ongoing understanding of his experience was shaped by multiple constructs, such as internal narratives of moral dilemmas and "what if" scenarios. He came to adopt various (sometimes-contradictory) subject positions: from Good Samaritan, to patriotic vigilante, to potential victim of a blood-borne disease.

It is clear why Fast says that he was drawn to Martin's experience because of its various elements of "mistaken identity" (Fast 33). As the quote at the beginning of this section demonstrates, Fast considers a performative aspect of role-playing to be fundamental to the encounter between artist and subject. More significantly, Fast's artwork also highlights the shifting roles and subject positions internal to the original event itself. While Martin was conscious that as a medic his role was to offer assistance, he hesitated in doing so. In the instance of the event, Martin's moral obligation of what he "should" do clashed with an uncertainty in his role, and a desire to be a mere spectator and onlooker.

In Martin's story, there is already a sense of misrecognition and multiplicity of the subject, which Fast amplifies and supplements (and indeed overtakes) through his own personal fictionalisations. In the final video, Fast interweaves his original interview footage with a separate, fictionalised narrative (which Fast scripted): a behind-the-scenes scenario, which follows the mishaps of a group of filmmakers as they attempt to film a re-enactment of these events. Take a Deep Breath is very much about playing roles. Just as Martin's testimony is somewhat laboured, the actors' performances also seem purposefully forced. Central to all this is the role of "Omer", the slightly bumbling director whose attempts to recreate the suicide bombing are thwarted across the video's scenes.

Fast's work is always highly self-reflexive, but Take a Deep Breath is arguably his most self-conscious piece, featuring a number of strategies that break the "fourth wall" of representation. It is arranged as a dual-channel video (either projected or on two screens hung side-by-side), which often disrupts the visual continuity of the scenes and breaks the "180degree rule" of camerawork. Characters peer into the cameras, drawing attention to their presence, and actors break character at crucial moments. The "Omer" figure unconvincingly navigates these semi-farcical scenarios, unable to rescue his project from the issues besetting it. Being preoccupied with the difficulties and contradictions of representing "real stories", Take a Deep Breath narrates failure in a number of ways. The suicide bomber fails to kill any other people, and Martin fails to save his life. The video's three main scenes, trying to re-stage Martin's story, all involve unexpected disruptions. Its looped narrative structure-highly characteristic of Fast's practice more broadly (Warren) - eludes any form of resolution.

Failure is not the end of the story though; it is presented as a contingent part of creation, and crucially it informs Fast's use of fictionalised doubles. Fast reveals that his use of personas began through a: 
notion of not having moral certitude about what I was doing, understanding that I'm dealing with real people telling me their stories, and as a foil for that, as a buffer, needing to indicate that there's an [external artistic] agency involved [...]. So stemming from this very strong sense of shortcoming and failure, there is this desire to double me into the work. (Fast and Paulsen)

Fast doubles himself in response to a sense of uncertainty felt when representing real life. These semi-fictionalised doubles let Fast implicate himself in the process of representation, addressing the controversial or questionable decisions that any such process involves without adopting a moralising, alienating or speciously authoritative voice. As Fast says, the "Omer" "figure is also the fool" (Fast and Paulsen).

Fast's acts of doubling could be read as an example of contemporary art's general obsession with self-reflexivity, one of the "endless art cliches [sic]" that "[art] should transcend its form", as one reviewer of Take a Deep Breath observed (Johnson). However Fast's personas are not purely inward looking; they break the boundaries of the text and open it to connections that cannot be contained within the artwork itself. Once doubled into Take a Deep Breath, Fast's character becomes a destabilising presence. The audience must grapple with a "real" story, restaged by a "fictional" version of a "real" person-what art historian Maria Muhle describes as a spiralling "re-enactment of the imaginary filming of an impossible real event". iv Take a Deep Breath knowingly and gleefully collapses the boundaries between documentary and fictional modes. Fast's parafictional persona is not primarily focussed on the contestation of himself as an individual. His self-reflexivity is born out of (even necessitated by) the already conflicted nature of Martin's experience and testimony. Fast is highly aware of the difficulties of establishing a representative relationship with the "real life" events recounted, saying that "it is impossible [...] to create a direct translation of that [...] and so the work proposes a game of substitution" (Fast and Verhagen 4).v He is understandably sceptical about artists' and filmmakers' abilities (himself included) to "realistically" represent real stories. While this may indeed be an impossible goal, it nonetheless often remains a normative ideal of filmmaking.

Fast repeats this strategy of doubling himself in a number of subsequent videos. In a related project, the artist book In Memory: Omer Fast (2010), he constructs a more open-ended persona. The book is a collection of essays written about Fast's practice, which the artist extensively annotated with a series of, as he says, "partly fictional, sometimes very fictional, sometimes not so fictional notes" (Fast and Heck). Here Fast acts as an unreliable commentator, usurping the traditional function of a citation. They do not clarify details or specify sources, rather they open up the text to a raft of plausible narratives, entertaining imaginations and absurdist speculations. Fast's artworks layer his subjects with alternate fictions, veering off into productive (and provocative) new directions; any sense of discovering an original truth is always deferred and thwarted. vi Yet, when reading Fast's annotations, or when watching his various "Omer" characters, I nonetheless catch myself sometimes trying to "decipher" his spiralling layers of fiction, in spite of the clear impossibilities of doing so.

Fast's works rely on this ingrained desire to "decipher" meaning, as do many of the examples in this article. What emerges strongly from the examples discussed in this article are the abilities of parafictional personas to thoroughly embed fictional constructs within reality, particularly due to the difficulties in separating elements represented by the same proper name. Parafictional personas allow for multiple levels of fictionality and reality to co-exist; they generate a sense of open-endedness and irresolvability, continually forcing the question within the viewer of what "version" of the person is speaking. They also force the question of what version of history is being spoken, and what version is being received and internalised by the audience. Parafictional personas are often extremely pleasurable, but in their inherent 
irresolvabilities they can also frustrate the viewer. In doing so, they reveal how much viewers desire such continuities and how much we intuitively seek for truths, even when such truths are presented as contested, incomplete or problematic.

For the discipline of persona studies, parafictional personas may represent an extreme idea of the persona in general, which as Marshall, Moore and Barbour acknowledge always possesses an inherently fictive quality, because "it is a fabrication comprised from an interpretation of one's identity and how that identity is made into a public entity" (292). Marshall, for instance, has explored how actors can be overwhelmed by their characters, transforming into "a blended public person and the related personage" ("Seriality and Persona"). The examples that I have explored in this article expand this relationship to a new, extreme level. Parafictional personas actively perform and amplify these "blendings", and in fact they go further than "blurring the boundaries". They have the potential to render these distinctions - between truth and fiction, between an "originary" referent and its "external" supplement-as undecidable. This may be uncomfortable or disconcerting act for some viewers, but it is also the point where their critical potential emerges. Stephen Colbert expressed this potential early in his career, saying, "I would love people to not know necessarily when I mean what I'm saying. [...] [If] they don't know what side of an issue I'm on at times, that's fantastic" (60 Minutes). It is by way of their inherent uncertainty that parafictional personas address their viewers, potentially opening up spaces for criticality and further investigation. They afford artists and performers opportunities to challenge Osborne's "general ambiguity in the relationship between fictional and historical narratives" (34), because a sense of ambiguity is always already embedded in their construction.

\section{CONCLUSION}

Due to their overtly doubled nature, parafictional personas require their viewers to continually evaluate and oscillate between what they perceive as truth or fiction. Parafictional personas thus expose a persistent cultural tension: between wanting to pin down meaning and establish concrete "truths"; and the counteracting pleasures (and necessities) of uncertainty. Or as Lambert-Beatty argues, parafictions "train us in skepticism and doubt, but also, oddly, in belief" (78). Parafictional personas expose how much we as viewers (and societies) search for ideas of truth and resolution, even when they are explicitly presented or revealed to us as incomplete or questionable. Parafictional personas confound cultural desires to order, categorise and "make sense" of fragmented (sometimes incompatible) narratives. The act of appropriating and fictionalising one's own proper name means that there is no single, overarching ruse to be deciphered. Something always remains purposefully unsaid, unexplained, uncertain. Raad's performative lectures, or the various "Omer Fasts" that emerge across Fast's oeuvre, destabilise assumed distinctions between documentary and fiction. The key point is to emphasise that while this destabilisation does not always or even consistently occur, the fictional can achieve a truth status, as Lambert-Beatty says, "for some of the people some of the time" (56). Parafictions are in this sense "ethically risky" and vulnerable to criticism (Lambert-Beatty 66), however, their epistemological instabilities account for their appeal. There is an undeniable pleasure found in the uncertainty and undecipherability of these depictions. ${ }^{\text {vii }}$

As supplements to reality, parafictional personas are seductively dangerous, being engaging and seditious, entertaining and critical, ethical and unethical at the same time. Their inherent pleasure is a potent creative and artistic strategy, and a central driver to Fast's practice for example, who acknowledges his "contradictory responsibility" as an artist: "[You're] dealing with real sensitive subject matter. But you also have an obligation to do something good with it" 
(Fast and Heck). This is perhaps a strange articulation, however by "good" Fast refers to the responsibility towards creating artworks that have their own internal logic, coherence and appeal to the audience. Deploying fiction or parafiction may risk overtaking real subject matters. Yet in doing so, these strategies can do justice to their subjects not by attempting the impossible task of faithful representation, but by integrating them into new logics of representation. These artistic recourses to fiction do not reflect an indifference to "real life" issues; they do however posit fiction, at times, as a uniquely productive mode of approaching politically charged situations and historically complex stories.

\section{END NOTES}

i Playing oneself has become an extremely popular vehicle in commercial television; other examples include It's Garry Shandling's Show (1986-90), Ricky Gervais and Warwick Davis in Life's Too Short (2011-13), James Carville and Mary Matalin in Steven Soderbergh's K Street (2003), and less subversive examples like Matt LeBlanc in Episodes (2011-). Films including Coffee and Cigarettes (Jim Jarmusch, 2003), Pittsburgh (Chris Bradley and Kyle LaBrache, 2006), JCVD (Mabrouk El Mechri, 2008), Cold Souls (Sophie Barthes, 2009), Paper Heart (Nicholas Jasenovec, 2009), The Trip (Michael Winterbottom, 2010), Maladies (Carter, 2012), This Is The End (Seth Rogen and Evan Goldberg, 2013), L'enlèvement de Michel Houellebecq (Guillaume Nicloux, 2014) and 20,000 Days on Earth (Iain Forsyth and Jane Pollard, 2014) all revolve around the creation of parafictional personas for known figures.

ii Contemporary artists Richard Prince, Gregor Schneider, Lynn Hershman Leeson, Slater Bradley, William Powhida, Roee Rosen, Iris Häussler, Grayson Perry, and Adam Broomberg and Oliver Chanarin have all used personas and alter-egos in their practices.

iii Interestingly, Derrida appeared in Ken McMullen’s 1983 film Ghost Dance, playing himself.

iv Furthermore, as with my earlier example of $A$ Cock and Bull Story, Fast also encases his behind-the-scenes storyline in another "making of" construct.

v Here Fast is actually referring to a related work, The Casting (2007), but the sentiments remain relevant.

vi This is key creative strategy found across Fast's entire practice. While beyond the scope of this article, an early video such as Spielberg's List (2003), and a later installation The Forlorn Lover's Guide to the Underground and to Doubles (2009-10), are both key examples of works that are utterly disorientating in their multiplicity of truths, fictions and ambiguities.

vii I do not, however, want to imply that such personas are always progressive or selfcritical. Although beyond the scope of this article two recent examples-artist Richard Prince's controversial New Portraits (2014) series, and former Australian politician Mark Latham's "parody" Twitter account (@RealMarkLatham)_both involve the deceptive creation of trolling personas through social media.

\section{WORKS CITED}

81/2. Dir. Federico Fellini. Umbrella Entertainment. 1963. DVD.

20,000 Days on Earth. Dir. Iain Forsyth and Jane Pollard. Madman Entertainment. 2014. Film. 
All That Jazz. Dir. Bob Fosse. 20th Century Fox Home Entertainment. 1979. DVD.

Barbour, Kim, P. David Marshall and Christopher Moore. "Persona to Persona Studies". $M / C$ Journal17.3 (2014). Web. 10 Mar. 2016.

Being John Malkovich. Dir. Spike Jonze. United International Pictures (UIP). 1999. Film.

Campany, David. "Adam Broomberg \& Oliver Chanarin”. ArtReview 50 (2011): 80-3. Print.

Casavecchia, Barbara. "Walid Raad". Frieze 17 Jul. 2009. Web. 26 Jan. 2016.

A Cock and Bull Story. Dir. Michael Winterbottom. Redbus Film Distribution. 2005. Film.

Coffee and Cigarettes. Dir. Jim Jarmusch. United Artists. 2003. Film.

The Colbert Report. Comedy Central. 2005-14. Television.

"The Colbert Report". 60 Minutes. CBS, 20 Apr. 2006. Web. 10 Jul. 2014.

Cold Souls. Dir. Sophie Barthes. Madman Entertainment. 2009. DVD.

The Congress. Dir. Ari Folman. ARP Sélection. 2013. Film.

Cotter, Holland. "Is It Reality or Fantasy? The Boundaries Are Blurred". The New York Times 8 Jan. 2010. Web. 12 Feb. 2011.

Curb Your Enthusiasm. Perf. Larry David. HBO. 2000-. Television.

Darwent, Charles. "5,000 Feet is the Best-How Truth and Fiction Became Blurred". The Independent 25 Aug. 2013. Web. 3 Apr. 2015.

D'Cruz, Glenn. "Darkly Dreaming (in) Authenticity: The Self/Persona Opposition in Dexter". $M / C$ Journal 17.3 (2014). Web. 10 Mar. 2016.

Derrida, Jacques. "Signature Event Context." In Limited Inc. Trans. Jeffrey Mehlman and Samuel Weber. Evanston: Northwestern University Press, 1988. 1-23. Print.

---. Of Grammatology. Trans. Gayatri Chakravorty Spivak. Baltimore; London: Johns Hopkins University Press, 1976. Print.

dOCUMENTA (13). "Scratching on Things I Could Disavow". Web. 1 Jul. 2014.

L'enlèvement de Michel Houellebecq. Dir. Guillaume Nicloux. Le Pacte. 2014. Film.

Enwezor, Okwui. Archive Fever: Uses of the Document in Contemporary Art. New York: International Center of Photography; Göttingen: Steidl Publishers, 2008. Print.

Episodes. Showtime. 2011-. Television.

Fast, Omer. In Memory: Omer Fast. Ed. Sabine Schaschl. Berlin: The Green Box, 2010. Print.

Fast, Omer and Marina Vinyes Albes. "Interview: 'Present Continuous'”. Le Magazine, Jeu de Paume Gallery, 13 Oct. 2015. Web. 27 Jan. 2016.

Fast, Omer and Petra Heck. "Omer Fast Interview". Nederlands Instituut voor Mediakunst, 18 Jan. 2011. Web. 10 Oct. 2014.

Fast, Omer and Kris Paulsen. "Omer Fast and Kris Paulsen: A Conversation". Wexblog 9 Jul. 2012. Web. 11 Oct. 2012.

Fast, Omer and Marcus Verhagen. "Pleasure and Pain". Art Monthly 330 (2009): 1-4. Print.

Foster, Hal. "An Archival Impulse". October 110 (2004): 3-22. Print.

---. "The Artist as Ethnographer". The Return of the Real: The Avant-Garde at the End of the Century. Cambridge, Mass.: MIT Press, 1996. 171-204. Print.

Foucault, Michel. The Archaeology of Knowledge and the Discourse on Language. Trans. A.M. Sheridan Smith. New York: Pantheon Books, 1972. Print.

Godfrey, Mark. "The Artist as Historian". October 120 (2007): 140-72. Print.

Ghost Dance. Dir. Ken McMullen. Mediabox Limited. 1983. DVD.

House of Cards. Netflix. 2013-. Television.

It's Garry Shandling's Show. Showtime. 1986-90. Television.

JCVD. Dir. Mabrouk El Mechri. Revolver Entertainment. 2008. DVD.

Johnson, Paddy. "Films within Films". The L Magazine 12 Feb. 2010. Web. 3 Feb. 2012.

KStreet. Dir. Steven Soderbergh. Perf. James Carville, Mary Matalin. HBO. 2003. Television.

Klein, Naomi. "The Year of the Fake". The Nation 8 Jan. 2004. Web. 12 Jul. 2014.

Lambert-Beatty, Carrie. "Make-Believe: Parafiction and Plausibility". October 129 (2009): 5194. Print.

Lebovici, Elisabeth. "From Homer to Omer Fast". Afterall 20 (2009). Web. 7 Jul. 2011.

Lee, Soojin. "The Art and Politics of Artists' Personas: The Case of Yayoi Kusama". Persona Studies 1.1 (2015): 25-39. Web. 10 Mar. 2016. 
Lewis-Kraus, Gideon. “The Reanimator: Omer Fast's Virtual Realities”, Nextbook 30 Apr. 2008. Web. 1 Jun. 2015.

Life's Too Short. Perf. Ricky Gervais, Warwick Davis. BBC. 2011-13. Television.

Louie. Perf. Louis C.K. FX Network. 2010-. Television.

Maladies. Dir. Carter. Tribeca Film. 2012. DVD.

Marshall, P. David. "Persona Studies: Mapping the Proliferation of the Public Self". Journalism 15.2 (2014): 153-70. Print.

---. "Seriality and Persona”. M/C Journal 17.3 (2014). Web. 10 Mar. 2016.

Marshall, P. David and Kim Barbour. "Making Intellectual Room for Persona Studies: A New Consciousness and a Shifted Perspective”. Persona Studies 1.1 (2015): 1-12. Web. 10 Mar. 2016.

Marshall, P. David, Christopher Moore and Kim Barbour. "Persona as Method: Exploring Celebrity and the Public Self Through Persona Studies". Celebrity Studies 6.3 (2015): 288-305. Web. 10 Feb. 2016.

MoMA. "Scratching on Things I Could Disavow: Walkthrough". The Museum of Modern Art (MoMA), New York. Web. 10 Mar. 2016.

Muhle, Maria. "Omer Fast: Where Images Lie ... About the Fictionality of Documents". Afterall 20 (2009). Web. 7 Jul. 2011.

Osborne, Peter. Anywhere Or Not At All: Philosophy of Contemporary Art. London; New York: Verso, 2013. Print.

Page, Ruth E. Stories and Social Media: Identities and Interaction. New York: Routledge, 2012. Print.

Paper Heart. Dir. Nicholas Jasenovec. Anchor Bay Entertainment. 2009. DVD.

Piper, Melanie. "Louie, Louis: The Fictional, Stage, and Auteur Personas of Louis C.K. in Louie". Persona Studies 1.1 (2015): 13-24. Web.

Pittsburgh. Dir. Chris Bradley and Kyle LaBrache. Starz Home Entertainment. 2006. DVD.

Raad, Walid. "I Have Already Been in the Lake of Fire". Framework 43.2 (2002): 42-63. Print.

Ritchin, Fred. Bending the Frame: Photojournalism, Documentary, and the Citizen. New York: Aperture, 2013. Print.

Roelstraete, Dieter. "After the Historiographic Turn: Current Findings." e-flux journal 6 (2009). Web. 2 Apr. 2014.

Rooney, Kara L. "Walid Raad". The Brooklyn Rail11 Dec. 2009. Web. 10 Mar. 2016.

Seinfeld. NBC. 1989-98. Television.

Sharro, Karl. "Traces of the Future". Culture Wars 21 Oct. 2010. Web. 10 Jul. 2015.

This Is The End. Dir. Seth Rogen and Evan Goldberg. Sony Pictures Releasing. 2013. Film.

The Trip. Dir. Michael Winterbottom. BBC/Madman Entertainment. 2010. Television and Film.

Warren, Kate. "Gallery Repetitions". Le Magazine, Jeu de Paume Gallery, 20 Jan. 2016. Web. 1

Feb. 2016. 